\title{
Intercalation experiments for morphological alteration of kaolinite present in iron ore tailings
}

\section{(Experimentos de intercalação para alteração morfológica da caulinita presente em rejeitos de mineração de ferro)}

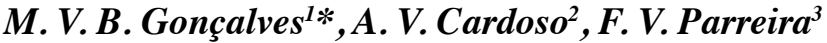 \\ ${ }^{I}$ Federal University of Ouro Preto, REDEMAT, Pç. Tiradentes 20, 35400-000, Ouro Preto, MG, Brazil \\ ${ }^{2}$ University of the State of Minas Gerais, School of Design-REDEMAT, 31270-010, Belo Horizonte, MG, Brazil \\ ${ }^{3}$ Vale S.A., Ferrous Technology Center, 34006-270, Nova Lima, MG, Brazil
}

\begin{abstract}
The main aim of this work was to evaluate the use of kaolinite present in iron ore tailings (IOT) in the synthesis of halloysitelike structures. The segregation of kaolinite was performed by acid leaching of the IOT. Three steps were strictly controlled for the efficacy of the synthesis procedure: i) pre-intercalation of the clay mineral using dimethyl sulfoxide; ii) obtaining the methoxy-modified kaolinite; iii) intercalation of the methoxy-kaolinite with suitable organic molecules. The synthesis procedure was performed in one-step and two-step. X-ray diffraction result showed that the product obtained from the IOT was composed essentially of kaolinite. The leaching was efficient in concentrating the kaolinite, considerably increasing the percentage of this clay mineral in the segregated product. Apparently, the contamination of $\mathrm{Fe}^{3+}$ ions did not interfere in the synthesis process. FESEM images indicated the morphological transformation of plate-like kaolinite for kaolinite nanotubes with a halloysite-like structure.
\end{abstract} Keywords: iron ore tailings, kaolinite, intercalation, nanotubes, halloysite.

Resumo

O principal objetivo deste trabalho foi avaliar o uso da caulinita presente no rejeito de mineração de ferro (RMF) na síntese de estruturas semelhantes à haloisita. A segregação da caulinita foi realizada por meio da lixiviação ácida do RMF. Três etapas foram rigorosamente controladas para eficácia do procedimento de síntese: i) pré-intercalação do argilomineral usando dimetilsulfóxido; ii) obtenção da caulinita metoxi-modificada; iii) intercalação da metoxi-caulinita com moléculas orgânicas adequadas. $O$ procedimento de síntese foi realizado em uma etapa e duas etapas. $O$ resultado de difração de raios $X$ mostrou que o produto obtido do RMF foi composto essencialmente por caulinita. A lixiviação foi eficiente para concentrar a caulinita, aumentando consideravelmente o percentual deste argilomineral no produto segregado. Aparentemente, a contaminação por íons de Fe ${ }^{3+}$ não interferiu no processo de síntese. Imagens de MEVFEG indicaram a transformação morfológica das placas de caulinita para nanotubos de caulinita com estrutura semelhante à haloisita.

Palavras-chave: rejeito de mineração de ferro, caulinita, intercalação, nanotubos, haloisita.

\section{INTRODUCTION}

In recent years, an increase in iron ore production has been observed, making interactions between this technique and the environment important. One of the main aspects related to iron production is the large volume of tailings generated in the beneficiation stage, the treatment given to the ore to maximize the use of the material of interest. Recently, due to the high demand for iron ore, rocks with low levels of iron are now feasible, implying an increase in the volume of tailings generated [1]. To maximize yield in the process of obtaining iron and exploiting the unrecovered materials of interest that are released together with the tailings, mining companies have been striving to improve mineral processing

*m.vitorbg@gmail.com

Dhttps://orcid.org/0000-0002-2047-0777 techniques to minimize the losses in the beneficiation stage and reprocessing the tailings generated, and also developing technologies to develop new applications and/or products using, for example, the clay minerals contained in iron ore tailings. In general, the minerals identified in iron ore tailings (IOT) are hematite, goethite, gibbsite, muscovite, quartz, and kaolinite. Kaolinite $\left[\mathrm{Al}_{2}(\mathrm{OH})_{4} \mathrm{Si}_{2} \mathrm{O}_{5}\right]$ is a clay mineral belonging to the kaolin group and occurs in the plate-like shape. The kaolinite can be subjected to the intercalation process that is used as a strategy to expand the interlayer space of clay minerals. Nanosized tubular halloysite, also called halloysite nanotube (HNT), is the most common occurrence of clay mineral halloysite that belongs to the kaolin group and, similar to kaolinite, is a phyllosilicate where each layer is formed by an octahedral alumina sheet and a silica tetrahedral sheet in a 1:1 stoichiometric ratio. HNT vary in length from the submicron scale up to ca. $30 \mu \mathrm{m}$. Generally, internal 
diameters range from ca. 10 to $100 \mathrm{~nm}$ and internal diameter from ca. 20 to $190 \mathrm{~nm}[2,3]$. In the HNT, the outer surface is formed by siloxane ( $\mathrm{Si}-\mathrm{O}-\mathrm{Si}$ ) groups (tetrahedral sheet) and a gibbsite matrix composed of aluminol (Al-OH) groups (octahedral sheet) is present at the inner surface $[4,5]$. Chemically, halloysite and kaolinite are similar, except that the halloysite layers are separated by a monolayer of water molecules; thus, the halloysite has the structural formula $\mathrm{Al}_{2}(\mathrm{OH})_{4} \mathrm{Si}_{2} \mathrm{O}_{5} \cdot \mathrm{nH}_{2} \mathrm{O}$. When hydrated $(\mathrm{n}=2)$, it is called 'halloysite $10 \AA$ ', and $10 \AA$ indicates the $\mathrm{d}_{001}$ value of the layers. The dehydrated structure $(n=0)$ is called 'halloysite $7 \AA$ '.

The tubular structure of halloysite results from the wrapping of the 1:1 clay mineral layers under favorable geological conditions and is driven by the mismatch between the tetrahedral and octahedral sheets. In order to understand the rolling mechanism of the 1:1 layer of tetrahedral and octahedral sheets, several models have been proposed [6]. Increasing demand for HNT is observed, although it is not as common as kaolinite [7-9]. In recent years, several studies have broadened the field of application of HNT to highly technological applications such as catalytic supports and other functional materials due to their particular morphology and specific properties $[8,10]$. In addition, the nanoparticles are also capable of adsorbing and storing a large number of hydrogen molecules [11] and drugs for controlled release [12-14], forming antibacterial biological membranes [15] and polymer-based composites [16-18], among other technological uses. Obtain a halloysite-like structure, based on the rolling of the kaolinite layers, has attracted the attention of several researchers [9, 19-26]. According to [9, 22], HNT has noble applications in nanotechnology; however, deposits of this clay mineral with attractive quality are rare worldwide. Besides, the presence of associated impurities and the morphology of HNT found in nature may not be uniform; therefore, the synthesis of nanotubes from intercalated and delaminated kaolinite is an important issue to be treated.

Although kaolinite occurs naturally in the plate-like shape, it has been shown to be susceptible to transform into nanotubes through intercalation/deintercalation methods. According to [6], kaolinite layers curl to compensate for the lateral misfit between the tetrahedral and octahedral sheets when the hydrogen bonds between the layers are sufficiently weakened. When water molecules occur between the 1:1 layers, similar to the halloysite structure, the interlayer force is weakened; therefore, the octahedral and tetrahedral sheets are free to approach their normal dimensions, which lead to a curvature of kaolinite layers [27]. In platy kaolinite, the structural stress generated by the mismatch between the tetrahedral and octahedral sheets is compensated by the formation of intense hydrogen bonds between the basal oxygen of the tetrahedral sheets and the inner-surface hydroxyl of the adjacent layer [28]. Gardolinsky and Lagaly [21], citing [6], stated that kaolinite layers curl to compensate the lateral misfit between larger tetrahedral sheets and smaller octahedral sheets when the interlayer hydrogen bonds are sufficiently weakened. In non-hydrated 1:1 platy particles, the tendency to make shorter interlayer hydrogen bonds provides an additional driving force to tetrahedral rotation [6]. Thus, tetrahedral rotation corrects the misfit of a non-hydrated structure, a result that cannot be accomplished by a rolling mechanism. The rolling mechanism is energetically more favorable than tetrahedral rotation but can only occur in sufficiently thin particles and weakened interlayer hydrogen bonds. The large basal space of the intercalation compounds prevents the reestablishment of hydrogen bonds between the layers of kaolinite, causing the rolling mechanism to occur to stabilize the clay mineral structure [21].

The layer delamination and curl procedure can be performed in one-step, where intercalation and swelling occur at the same time, or two-step, where intercalation and swelling occur separately. Three steps were strictly controlled for the efficacy of the synthesis procedure: i) pre-intercalation of the clay mineral; ii) obtaining the methoxy-modified kaolinite; iii) intercalation of the methoxy-kaolinite with suitable organic molecules $[22,25]$. When the synthesis process occurs in two steps, an additional deintercalation step becomes necessary. Thus, the objective of this study was to segregate kaolinite from the other mineral components present in the IOT, to use it as a raw material for the synthesis of halloysite-like nanotubes to compare its performance with high-purity products.

\section{EXPERIMENTAL}

Materials and methods: iron ore tailings (IOT), collected from the thickener underflow of an iron ore industry (Vale S.A., Minas Gerais, Brazil), were selected for their kaolinite content and one sample with relatively high kaolinite content $(\sim 9.7 \%)$ was selected for this study. Two samples of high purity kaolinite (Standard Amazon, Amazon Basin, Brazil, and Sigma-Aldrich) were also used as received without further purification. The chemical composition of Amazon kaolinite (K-A) and Sigma-Aldrich kaolinite (K-SA) was determined by chemical analysis, and the results were expressed in the respective oxide form; iron content was determined using a wet method; the other elements were analyzed using

Table I - Results of chemical analysis (wt\%) of the samples K-A and K-SA.

[Tabela I - Resultados de análise química (\% em massa) das amostras K-A e K-SA.]

\begin{tabular}{cccccccccccc}
\hline Sample & $\mathrm{Fe}_{2} \mathrm{O}_{3}$ & $\mathrm{SiO}_{2}$ & $\mathrm{Al}_{2} \mathrm{O}_{3}$ & $\mathrm{P}_{2} \mathrm{O}_{5}$ & $\mathrm{MnO}$ & $\mathrm{CaO}$ & $\mathrm{MgO}$ & $\mathrm{TiO}_{2}$ & $\mathrm{Na}_{2} \mathrm{O}$ & $\mathrm{K}_{2} \mathrm{O}$ & LOI \\
\hline K-A & 1.66 & 44.77 & 38.20 & 0.20 & 0.00129 & 0.0150 & 0.021 & 0.963 & 0.239 & 0.009 & 14.09 \\
K-SA & 0.44 & 49.14 & 35.21 & 0.38 & 0.00052 & 0.0093 & 0.133 & 0.336 & - & - & 11.97 \\
\hline
\end{tabular}

LOI - loss on ignition. 
inductively coupled plasma optical emission spectroscopy (ICP-OES). The iron content of the samples was determined by the titanium (III) chloride reduction method, according to ABNT NBR ISO 2597-2 [29], in which the titration is based on an oxy-reduction reaction between the titrate $\left(\mathrm{Fe}^{2+}\right)$ and the titrant $\left(\mathrm{K}_{2} \mathrm{Cr}_{2} \mathrm{O}_{7}\right)$. Approximately $0.400 \mathrm{~g}$ of each sample was dissolved in hot $\mathrm{HCl}$, reduced, oxidized, and finally titrated with a standard potassium dichromate solution to determine iron content. For ICP-OES analysis, approximately $0.200 \mathrm{~g}$ of each sample was weighed in platinum crucibles, fused with sodium tetraborate and sodium carbonate, and then solubilized with $25 \%$ (v/v) $\mathrm{HCl}$ solution and diluted to $100 \mathrm{~mL}$ with distilled water. The results of the chemical analysis of K-A and K-SA are shown in Table I.

Hydrochloric acid ( $\mathrm{HCl}, \quad$ Fmaia), dimethyl sulfoxide (DMSO, Fmaia), methanol (MeOH, Fmaia), cetyltrimethylammonium chloride (CTMACl, SigmaAldrich), cetyltrimethylammonium bromide (CTAB, Sigma-Aldrich), isopropanol (Fmaia), 1,4-dioxane (Fmaia), ethanol (Fmaia) and hexylamine (C6N, Fmaia) of analytical grade purity $(>99.0 \%)$ were used as received. To segregate the kaolinite from the IOT, acid leaching was performed using a hydrochloric acid solution and distilled water, 70\% $(\mathrm{v} / \mathrm{v})$. To this solution, a certain amount of iron ore tailings (solid:liquid=1:6) was added at $120^{\circ} \mathrm{C}$ for $2 \mathrm{~h}$. After cooling, the acid-insoluble residue was separated by vacuum filtration, dried in air and stored for further characterization and synthesis studies. To prepare DMSO-intercalated kaolinite (kaoliniteDMSO), $10 \mathrm{~g}$ of kaolinite (high-purity and IOT segregated) was added into a mixture of $60 \mathrm{~mL}$ DMSO and $10 \mathrm{~mL}$ distilled water, stirred and refluxed at $150{ }^{\circ} \mathrm{C}$ for $7 \mathrm{~h}$. The solid in the mixture was separated by centrifugation and washed 3 times using 1,4-dioxane and isopropanol to eliminate the excess DMSO. The product was dried at $60{ }^{\circ} \mathrm{C}$ for $24 \mathrm{~h}$ [25]. To prepare methoxy-modified kaolinite (kaolinite-MeOH), 5 $\mathrm{g}$ of kaolinite-DMSO was added into $100 \mathrm{~mL}$ of methanol $(\mathrm{MeOH})$ and stirred for 7 days at room temperature. The solid in the mixture was separated by centrifugation and used while wet for the synthesis process [25]. To prepare halloysitelike nanotubes in a one-step route, approximately $1 \mathrm{~g}$ of wet kaolinite-MeOH was added into a $40 \mathrm{~mL} \mathrm{MeOH}$ solution of CTMACl $1 \mathrm{M}$ and $40 \mathrm{~mL} \mathrm{MeOH}$ solution of CTAB $1 \mathrm{M}$ and both stirred at $80{ }^{\circ} \mathrm{C}$ for $24 \mathrm{~h}$. The solid in the mixture was separated by centrifugation, washed 6 times with ethanol to remove the agent (CTMACl and CTAB) excess, and then dried at room temperature. To prepare halloysite-like nanotubes in a two-step route, approximately $0.5 \mathrm{~g}$ of wet kaolinite- $\mathrm{MeOH}$ was added into $15 \mathrm{~mL}$ of $\mathrm{C} 6 \mathrm{~N}$. The intercalation compounds were redispersed in 1,4-dioxane $(20 \mathrm{~mL})$ and sonicated for 10 $\min$ for the swelling. The process was repeated 3 times.

Instrumental techniques: powder X-ray diffraction (XRD) patterns were obtained using a PANalytical Empyrean with CoK $\alpha$ radiation $(\lambda=1.78896 \mathrm{~nm})$ operating at $40 \mathrm{kV}$ and 40 $\mathrm{mA}$. The diffractograms were obtained in the range $5-80^{\circ}(2 \theta)$ with a step size of $0.013^{\circ}$. Mössbauer spectra were collected at room temperature $(298 \mathrm{~K})$ with a spectrometer operating in constant acceleration mode with triangular reference signals using a ${ }^{57} \mathrm{Co}$ source diffused on an $\mathrm{Rh}$ sheet. The data accumulation was done with a multichannel analyzer with 1024 channels and a speed range of -11 to $+11 \mathrm{~mm} / \mathrm{s}$. The calibration of the spectrometer was done by collecting the spectra of the metallic iron at room temperature. The spectrum adjustment was performed using Lorentzian lines. The numerical results of the adjustments are reported as the hyperfine parameters, which are the magnetic hyperfine field $\left(\mathrm{B}_{\mathrm{hf}}\right)$ given in $\mathrm{T}$, relative subspectral area (RA) in \%, quadrupole splitting $\left(2 \varepsilon_{\mathrm{Q}}\right)$ and isomer shift $(\delta)$ given in $\mathrm{mm} / \mathrm{s}$. Isomer shifts are given with reference to metallic iron $(\alpha$ $\mathrm{Fe}$ ) at room temperature. The samples (high-purity and IOT segregated kaolinites) were previously sprayed. Samples for field emission gun scanning electron microscopy (FESEM) were analyzed with a FEI Quanta FEG 3D microscope. The clay mineral powder was ultrasonically dispersed in ethanol for $10 \mathrm{~min}$, rested on a silicon base, and then dried at room temperature; the samples were carbon-coated for FESEM. The equipment used for chemical analysis was the Varian 715-ES ICP-OES; the methodology used for sample preparation was described before.

\section{RESULTS AND DISCUSSION}

Initially, the characterization of the high-purity products was carried out to verify the chemical and morphological quality of the product segregated from IOT.
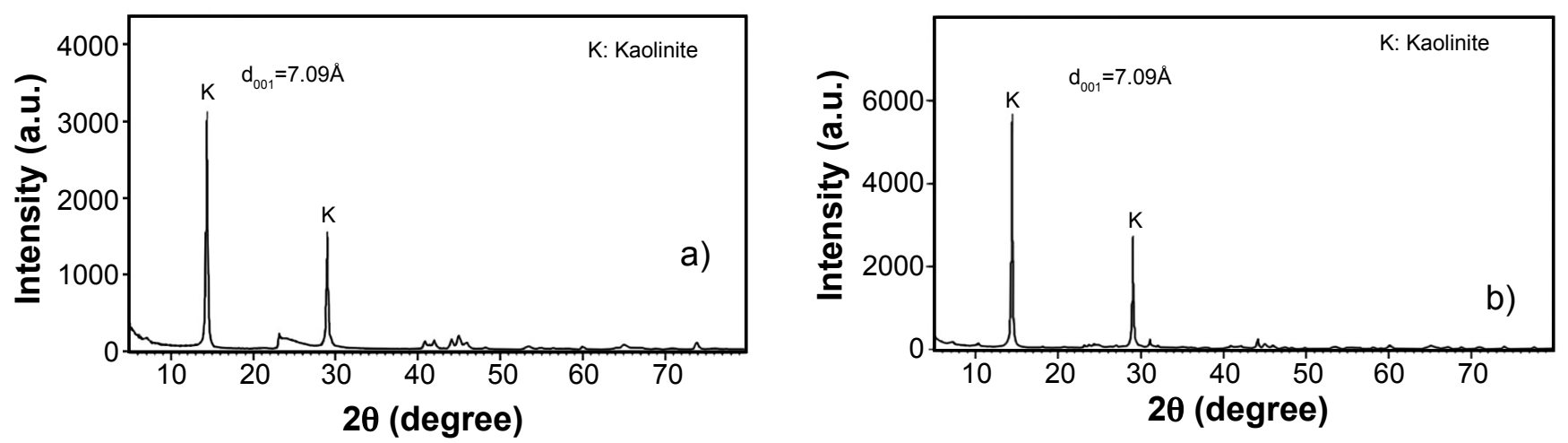

Figure 1: XRD patterns of high-purity kaolinite: a) K-A; and b) K-SA.

[Figura 1: Padrões de DRX de caulinita de elevada pureza: a) K-A; e b) K-SA.] 


\section{Amazon kaolinite and Sigma-Aldrich kaolinite}

$X R D$ : the X-ray diffractograms of $\mathrm{K}-\mathrm{A}$ and $\mathrm{K}-\mathrm{SA}$ are shown in Figs. 1a and 1b, respectively. Both kaolinite samples showed a typical diffraction pattern and were predominantly composed of clay mineral kaolinite, presenting a typical pattern of diffraction of a kaolin with a high degree of purity, that is, presented a well-defined and intense peak for kaolinite in its characteristic angle $\left(\sim 14^{\circ} 2 \theta, \operatorname{CoK} \alpha\right)$, which refers to the distance between planes (001) of the monoclinic structure, with characteristic basal reflection of $7.09 \AA\left(\mathrm{d}_{001}\right)$.

Mössbauer spectroscopy: the Mössbauer spectrum of the K-A (Fig. 2a) shows two components with very different isomer shifts $(\delta)$ and quadrupole splittings $\left(2 \varepsilon_{\mathrm{O}}\right)$ : i) a doublet of $\mathrm{Fe}^{3+}$ with $2 \varepsilon_{\mathrm{Q}}$ of $0.65 \mathrm{~mm} / \mathrm{s}$ and $\delta$ of $0.25 \mathrm{~mm} / \mathrm{s}$; ii) a doublet of $\mathrm{Fe}^{2+}$ with $2 \varepsilon_{\mathrm{O}}$ of $2.52 \mathrm{~mm} / \mathrm{s}$ and $\delta$ of $1.31 \mathrm{~mm} / \mathrm{s}$. The relative subspectral area (RA) of the $\mathrm{Fe}^{3+}$ doublet is $71 \%$, while that of the doublet $\mathrm{Fe}^{2+}$ is $29 \%$. The Mössbauer spectrum of the K-SA (Fig. 2b) show: i) a doublet of $\mathrm{Fe}^{3+}$ with $2 \varepsilon_{\mathrm{Q}}$ of $0.43 \mathrm{~mm} / \mathrm{s}$ and $\delta$ of $0.26 \mathrm{~mm} / \mathrm{s}$. According to [30-32], it is possible to predict that both samples have iron in the kaolinite structure. The $\mathrm{Fe}^{3+}$ doublet, identified in the two samples, indicated the presence of $\mathrm{Fe}^{3+}$ in an octahedral position of kaolinite, replacing $\mathrm{Al}$. The $\mathrm{Fe}^{2+}$ doublet, identified in the $\mathrm{K}-\mathrm{A}$, indicated the presence of $\mathrm{Fe}^{2+}$ in the octahedral position, assumed to be structural, substituting trioctahedral Al. However, according to the predicted values
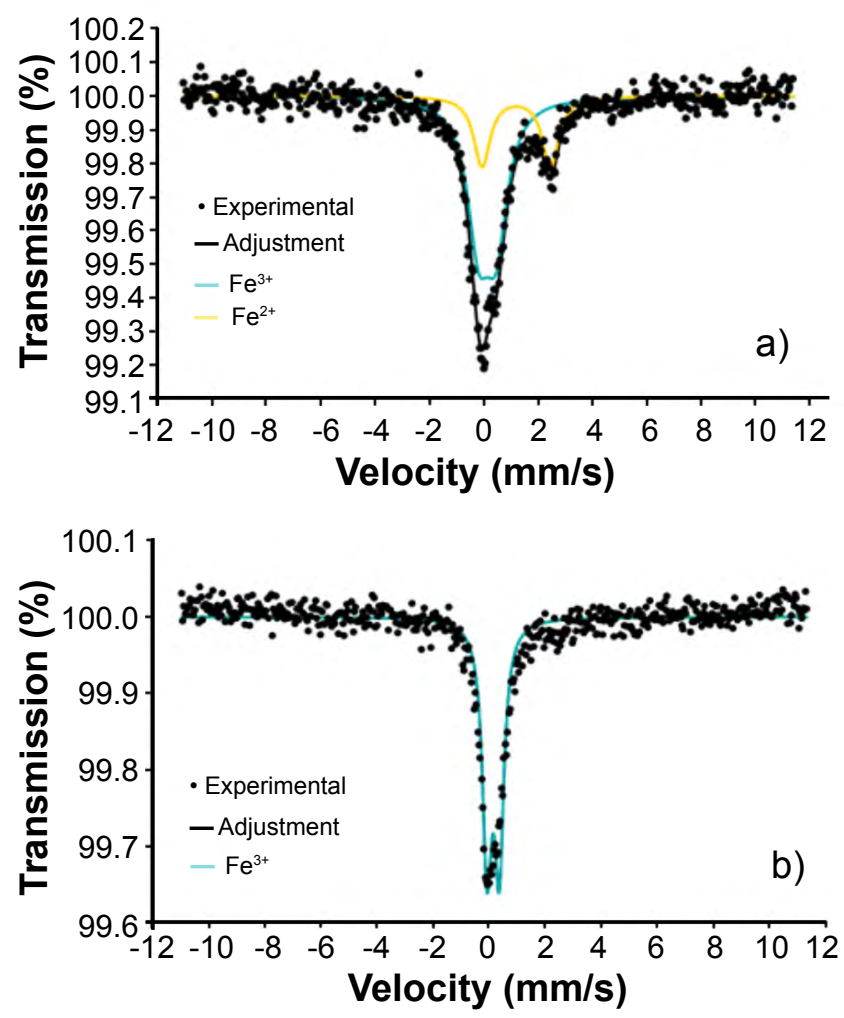

Figure 2: Mössbauer spectrum of the high-purity K-A (a) and K-SA (b).

[Figura 2: Espectro Mössbauer de caulinita de elevada pureza $K$-A (a) e $K-S A(b)$. in the literature, it is not possible to discard the possibility that iron was present in the muscovite structure. As the RA of the doublet is proportional to the amount of the structural iron in kaolinite, the structural octahedral $\mathrm{Fe}^{3+}$ content in the kaolinite was higher than the $\mathrm{Fe}^{2+}$ content.

FESEM: as indicated by the FESEM images of $\mathrm{K}-\mathrm{A}$ and K-SA (Fig. 3), the platy-like kaolinite particles were characterized by euhedral to subhedral crystals, the latter due to particles with irregular shapes, in plate-like shape with a predominantly hexagonal profile that reflected the well-defined pseudo-hexagonal character of the structure of this clay mineral. Sigma-Aldrich high-purity kaolinite (KSA) had a complex basal surface, showing large particles with a high occurrence of micro-islands with very small dimensions, also presenting broken and irregular edges. Although we cannot claim that there is a correlation between grain morphology and crystal structure only by SEM images, Zbick and Smart [33] and Du et al. [34] correlate complex characteristics and lamellar size with the degree of crystallinity of the clay mineral. This complex basal surface was similar to a poorly crystallized kaolinite described in [34]. Amazon kaolinite (K-A) presented a characteristic morphology of kaolinite derived from residual weathering, which is the incidence of this sample. Most crystals were small particles and had well-defined edges and angles, exhibiting typical kaolinite morphology with a pseudohexagonal plate showing low stacking levels. According to [33], these characteristics corresponded to well-crystallized kaolinite. However, small rounded crystal aggregates with smaller particle size coexisted.

According to [35], the presence of iron in the kaolinite structure contributes to the reduction of the structural order of clay mineral. According to the results of Mössbauer spectroscopy, both samples had structural $\mathrm{Fe}^{3+}$ ions. The results indicated that the presence of this ion did not directly affect regularity and the presence of surface defects of the clay mineral crystals. However, only in the structure of the $\mathrm{K}-\mathrm{A} \mathrm{Fe}{ }^{2+}$ ions were identified. The $\mathrm{Fe}^{2+}$, that replaces trioctahedral $\mathrm{Al}$, was responsible for the reduction of the structural order of the clay mineral, inducing the roundness of the crystals. This phenomenon was possibly due to an electrical deficiency; in this case, $\mathrm{Fe}^{2+}$ ions did not replace trioctahedral $\mathrm{Al}^{3+}$ ions at a ratio of $3 \mathrm{Fe}^{2+}: 2 \mathrm{Al}^{3+}$ to maintain charge neutrality $[36,37]$. It is well established that the $\mathrm{Si}$ tetrahedral sheet is larger than the Al octahedral sheet. This mismatch induces structural stress on the clay mineral that can be compensated by various types of structural distortion. One is the rotation of the tetrahedron from the ideal hexagonal arrangement to ditrigonal shape. The second is the slope of the tetrahedron, just as the basal oxygen does not occur in the same plane. The inclination of the tetrahedron takes the apical $\mathrm{Si}-\mathrm{O}$ bond to polarize from the perpendicular direction of the plane (001). However, distortions in the tetrahedron and octahedron cannot totally release stress, possibly due to interlayer hydrogen bonds. This accumulated stress is possibly the reason that large crystallites occur in the form of booklets, such as that shown in Sigma-Aldrich kaolinite. 

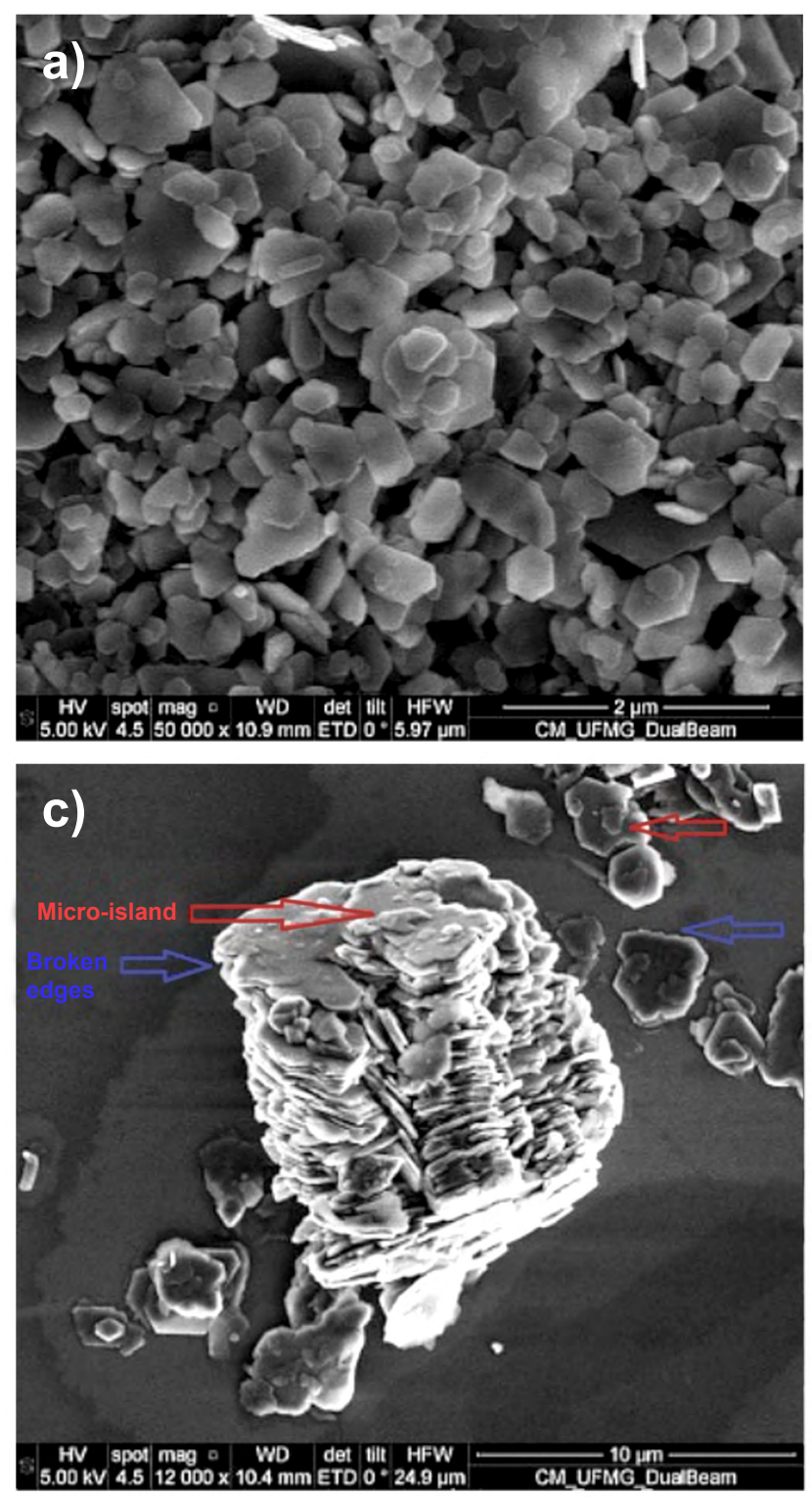

Figure 3: FESEM images of K-A (a,b) and K-SA (c,d).

[Figura 3: Imagens de MEVFEG de $K$-A $(a, b)$ e $K$-SA $(c, d)$.]

\section{Iron ore tailings and acid-insoluble residue}

The chemical composition of the selected IOT (Table II) showed that iron oxide, silica, and alumina were the major constituents. Silica and alumina were the major constituents of acid-insoluble residue (AIR) with minor amounts of iron oxide. The value of loss on ignition (LOI) of IOT was due to the presence of a substantial amount of moisture and structural water (loss by dehydroxylation of goethite and kaolinite).

$X R D$ : the XRD patterns in Figs. $4 \mathrm{a}$ and $4 \mathrm{~b}$ show the IOT before and after acid leaching, respectively. The solid product obtained after acid leaching is the AIR. Unlike IOT, which had hematite, goethite, quartz, and kaolinite as major phases, in AIR, the major mineralogical phases identified were muscovite, quartz, and kaolinite. It was possible to verify that the intensity of the characteristic
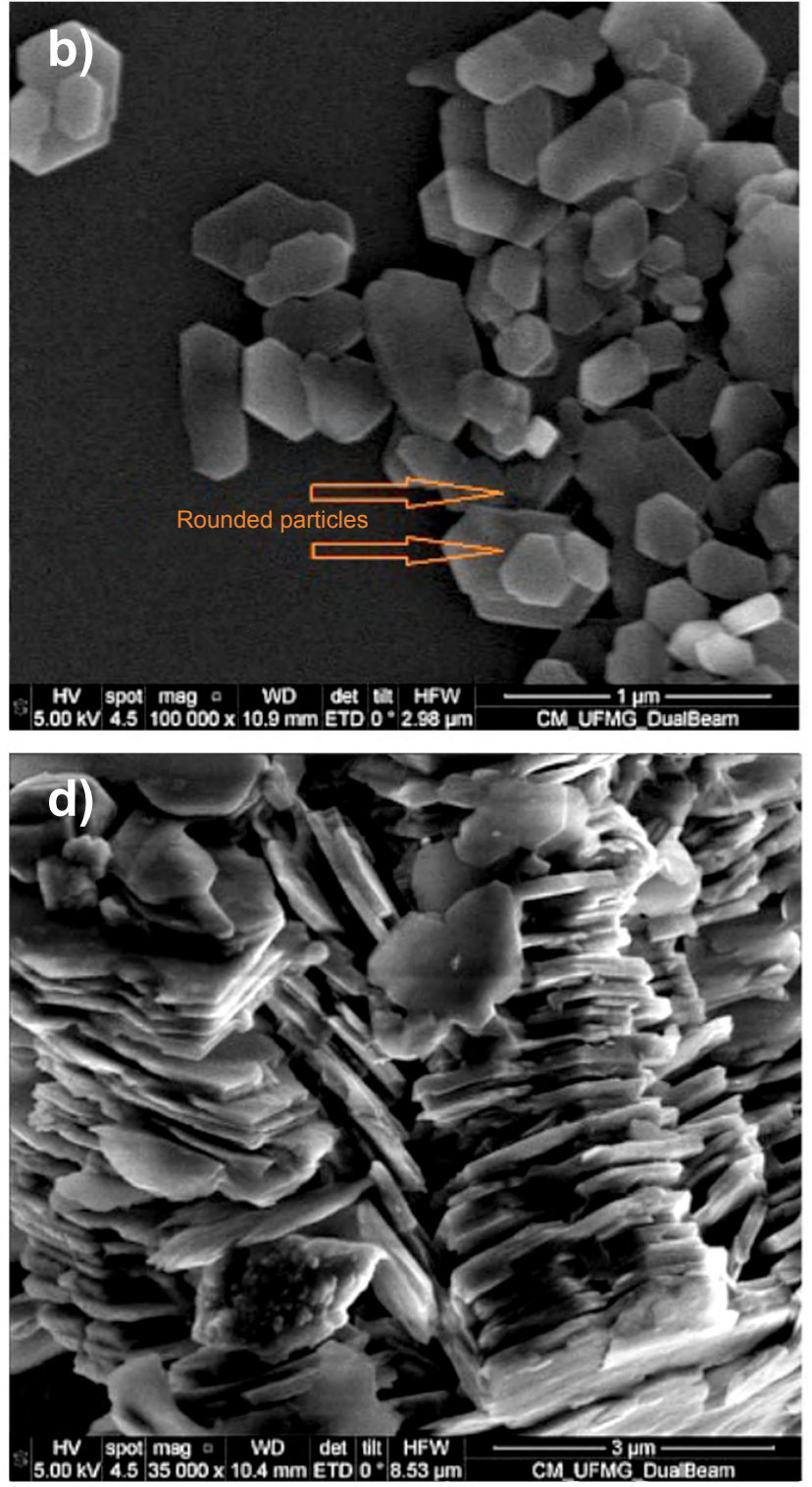

peak of kaolinite was higher than the other mineralogical phases, indicating the majority presence of the crystalline phase of this clay mineral. A quantitative analysis of the mineralogical composition of AIR was performed through the application of the Rietveld method. Comparing the final results of the quantification of the phases $(56 \%$ kaolinite, $2 \%$ hematite, $40 \%$ quartz, and $2 \%$ muscovite) with initial composition of IOT $(9.7 \%$ kaolinite, $23.8 \%$ hematite, $57.3 \%$ goethite, $8 \%$ quartz, and magnetite, gibbsite, and mica $<1 \%$ ), it is stated that there was a significant concentration of kaolinite. The presence of quartz was significant (40\%) because $\mathrm{HCl}$ used in leaching did not solubilize quartz. The quantitative value of kaolinite identified by applying the Rietveld method exceeded the value of a simple rational calculation. Considering that $18.33 \mathrm{wt} \%$ of the alumina in AIR corresponded to kaolinite (excluding impurities such as alumina of gibbsite and muscovite), a maximum of $46.4 \%$ 
Table II - Results of chemical analysis (wt $\%$ ) of the IOT and AIR.

[Tabela II - Resultados de análise química (\% em massa) do IOT e AIR.]

\begin{tabular}{ccccccccccc}
\hline Sample & $\mathrm{Fe}_{2} \mathrm{O}_{3}$ & $\mathrm{FeO}$ & $\mathrm{SiO}_{2}$ & $\mathrm{Al}_{2} \mathrm{O}_{3}$ & $\mathrm{P}_{2} \mathrm{O}_{5}$ & $\mathrm{MnO}$ & $\mathrm{CaO}$ & $\mathrm{MgO}$ & $\mathrm{TiO}_{2}$ & LOI \\
\hline IOT & 72.26 & 0.148 & 12.77 & 6.28 & 0.36 & 0.36 & 0.011 & 0.136 & 0.216 & 7.80 \\
AIR & 0.32 & - & 73.63 & 18.33 & 0.11 & $<0.005$ & 0.006 & 0.103 & 0.748 & 6.94 \\
\hline
\end{tabular}

IOT - iron ore tailings; AIR - acid-insoluble residue; LOI - loss on ignition.
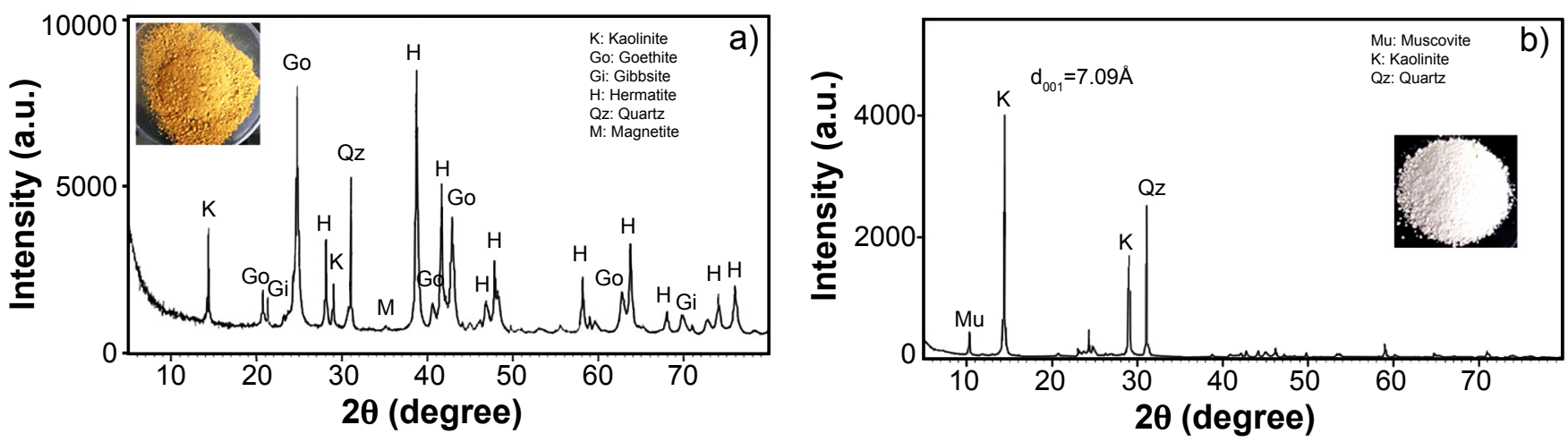

Figure 4: XRD patterns of IOT (a) and AIR (b); the inset shows the image of the sample.

[Figura 4: Padrões de DRX de IOT (a) e AIR (b); o inserto mostra imagem da amostra.]

of kaolinite should be obtained. The $56 \%$ kaolinite value obtained by the Rietveld method, therefore, exceeded an experimental margin of error, overestimating the result.

Comparing the AIR and IOT diffractograms, it is possible to affirm that the acid leaching procedure was adequate to concentrate the kaolinite present in the IOT, although the content of impurities such as quartz was high. The remaining ferrous phase, hematite, was present in very low quantity, practically undetectable by X-ray diffraction. It is emphasized that the mineralogical composition of the AIR resembled the mineralogical composition of K-SA, except for low amounts of remaining ferrous phases that could be eliminated by a low additional leaching time of the IOT. In addition, the $\mathrm{FeCl}_{3}$-rich liquor generated after the acid leaching of IOT can be used for the synthesis of alternative nanomaterials at a low cost, such as hematite nanoparticles [38], magnetite nanoparticles [39, 40], among others. Synthesis using this liquor minimizes the impact caused by this step of the kaolinite segregation process.

Mössbauer spectroscopy: the Mössbauer spectrum of the AIR (Fig. 5) shows three components: i) an external sextet due to hematite with a magnetic hyperfine field $\left(\mathrm{B}_{\mathrm{hf}}\right)$ of $51.6 \mathrm{~T}$, isomer shift $(\delta)$ of $0.37 \mathrm{~mm} / \mathrm{s}$, and quadrupole splitting $\left(2 \varepsilon_{\mathrm{Q}}\right)$ of $2.52 \mathrm{~mm} / \mathrm{s}$. These parameters were similar to standard hematite with high crystallinity and low (or no) isomorphic substitution [41]; ii) an internal sextet due to goethite with $B_{\text {hf }}$ of $38.0 \mathrm{~T}, \delta$ of $0.36 \mathrm{~mm} / \mathrm{s}$, and $2 \varepsilon_{\mathrm{Q}}$ of $-0.26 \mathrm{~mm} / \mathrm{s}$ [41]; iii) a doublet of $\mathrm{Fe}^{3+}$ with $2 \varepsilon_{\mathrm{O}}$ of $0.37 \mathrm{~mm} / \mathrm{s}$ and $\delta$ of $0.23 \mathrm{~mm} / \mathrm{s}$. It is suggested that this doublet is relative to the iron present in the clay mineral structure. The relative subspectral area (RA) of the hematite was $62 \%$, goethite was $28 \%$, and $\mathrm{Fe}^{3+}$ was $10 \%$. The low RA of this ion indicated a low presence of structural iron atoms $\left(\mathrm{Fe}^{3+}\right)$ in the clay mineral.

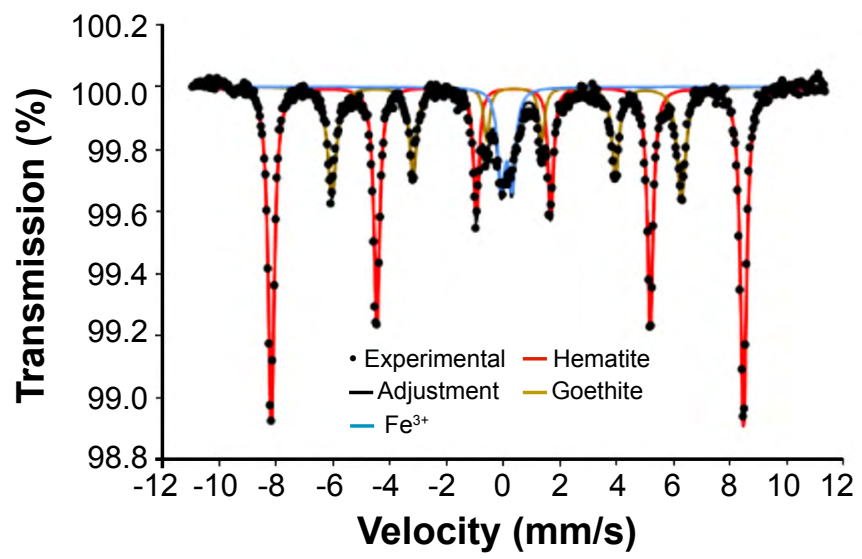

Figure 5: Mössbauer spectrum of AIR. [Figura 5: Espectro Mössbauer do AIR.]

FESEM: the FESEM images of AIR (Fig. 6) show that the obtained kaolinite presented similar morphology of K-A and K-SA. Similar to K-SA, the segregated product presented large crystallites, which justified the identification of booklet stacking, possibly due to high levels of structural stress [42]. However, there was a low occurrence of microislands and fewer occurrences of defects in the edges of the clay mineral, presenting a surface of lower complexity. These characteristics indicated well-crystallized kaolinite and confirmed that the presence of the structural $\mathrm{Fe}^{3+}$ ion does not directly affect the surface characteristics and crystallite size $[33,34]$.

\section{DMSO-intercalated kaolinite}

The pre-intercalation of kaolinite is the first step 

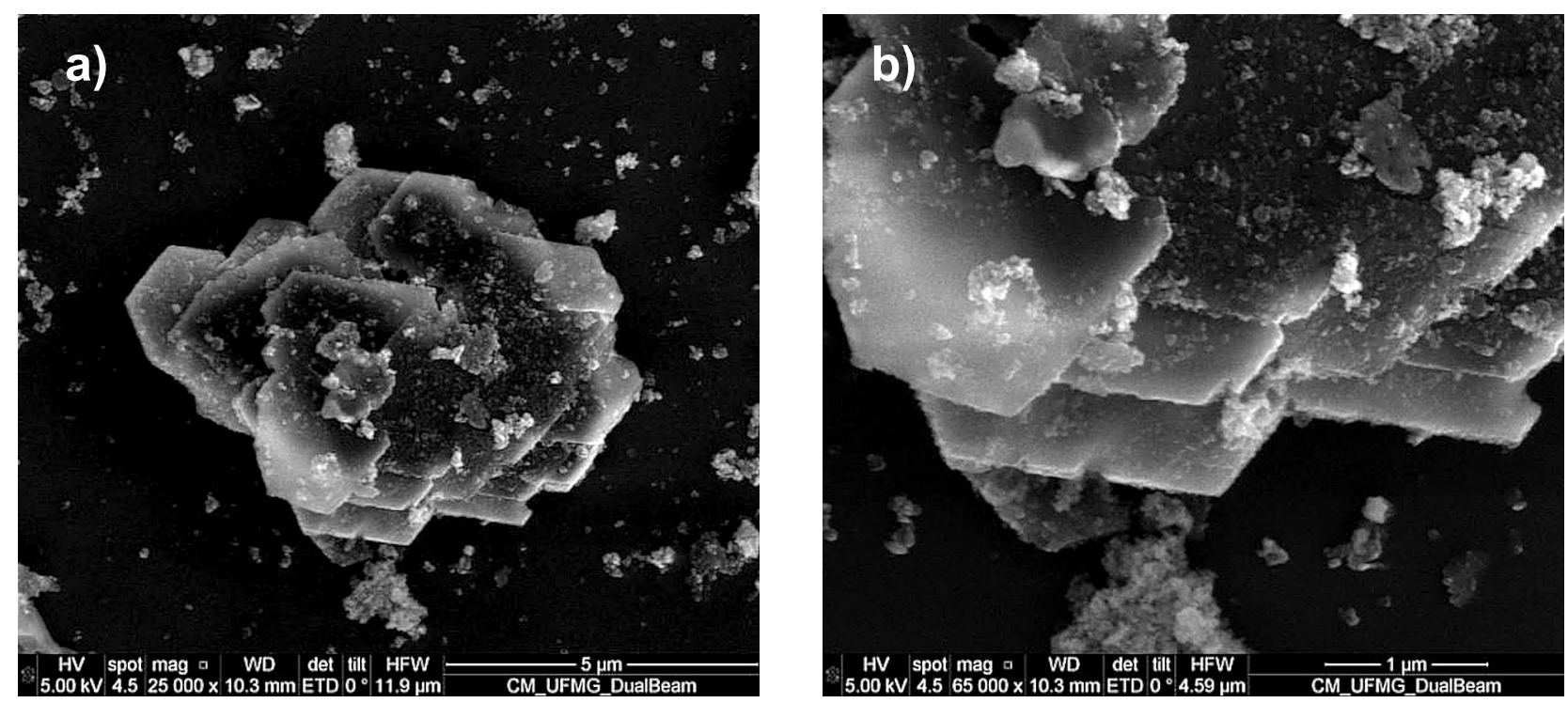

Figure 6: FESEM images of kaolinite present in AIR from IOT.

[Figura 6: Imagens de MEVFEG da caulinita presente no AIR obtido do IOT.]

responsible for increasing the distance between the kaolinite layers, and this procedure was performed with DMSO. The obtained kaolinite-DMSO exhibited XRD pattern similar to that of DMSO-intercalated kaolinite previously reported $[25,26,43-45]$. The diffraction pattern showed a significant change of the characteristic kaolinite peak from $\sim 14^{\circ} 2 \theta$ $\left(\mathrm{d}_{001}=7.09 \AA\right)$ to $\sim 9^{\circ} 2 \theta\left(\mathrm{d}_{001}=11.40 \AA\right.$, Fig. 7). This change is characteristic of the intercalation of a DMSO monolayer giving rise to a $4.31 \AA$ Ancrease in the basal space. In the three samples of kaolinite (high-purity and present in AIR), there was intercalation with DMSO with variation in the degree of intercalation. In the interlayer space of kaolinite, the oxygen of $\mathrm{S}=\mathrm{O}$ group of DMSO forms hydrogen bonds with inner surface hydroxyls of the gibbsite sheet of the kaolinite layer (O-H---O bonds) and one methyl group of DMSO is trapped into the ditrigonal hole in the tetrahedral sheet $(\mathrm{C}-\mathrm{H}---\mathrm{O}$ bonds) with the other S-C bond nearly parallel to this sheet [25].

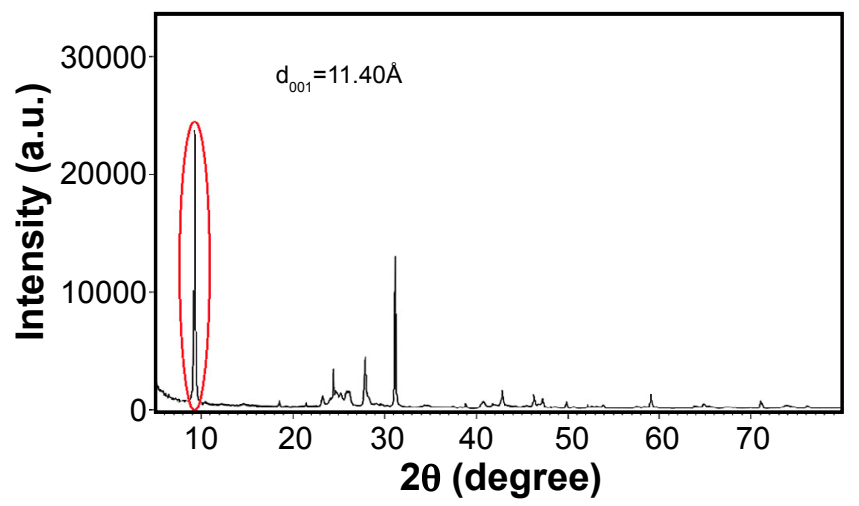

Figure 7: XRD pattern of the kaolinite-DMSO present in the AIR from IOT, highlighting the region that indicates DMSO-intercalated kaolinite.

[Figura 7: Padrão de DRX da caulinita-DMSO presente no AIR obtido do IOT, com destaque para a região que indica caulinita intercalada com DMSO.]
Differences in the degree of intercalation may be related to the crystallinity of kaolinite, the accumulated structural stress level (due to the mismatch between tetrahedral and octahedral sheets), the particle size of the crystallite, and the distribution of the defects of the clay mineral [23, 42 , $46,47]$. The highest degree of intercalation was achieved for K-SA and kaolinite present in AIR, both close to approximately $100 \%$ of intercalation (calculated by Eq. A), and it was lower for the K-A with approximately $76.7 \%$ of intercalation. These results indicated that the presence of $\mathrm{Fe}^{2+}$ ion, responsible for a decrease in the particle size of the crystallite, directly affected the intercalation rate.

$$
\text { \%intercaltion }=\frac{\mathrm{I}(001)_{\text {complex }}}{\mathrm{I}(001)_{\text {complex }}+\mathrm{I}(001)_{\text {kaolinite }}}
$$

where $\mathrm{I}(001)_{\text {complex }}$ and $\mathrm{I}(001)_{\text {kalinite }}$ are the intensities of (001) diffractions of DMSO-intercalated kaolinite and kaolinite, respectively [48]. K-SA and kaolinite in AIR had a larger crystallite particle size when compared to K-A, and was present in the form of booklets, possibly because they presented higher structural stress. The higher the stress, the faster and higher are the indexes of intercalation [42].

\section{Methoxy-modified kaolinite}

The synthesis of methoxy-kaolinite was performed to obtain an organic/inorganic hybrid with high reactivity and a hydrophobic interlayer able to inhabit the intercalating region (alkylamine or quaternary ammonium salt). In the three kaolinite samples, methoxy-modified kaolinite (kaolinite$\mathrm{MeOH}$ ) exhibited (001) diffractions with a $\mathrm{d}_{001}$ value of 10.80 $\AA$ (Fig. 8), with variations in the degree of intercalation, according to the DMSO intercalation. Kaolinite presents in the AIR from IOT had approximately $100 \%$ of intercalation 


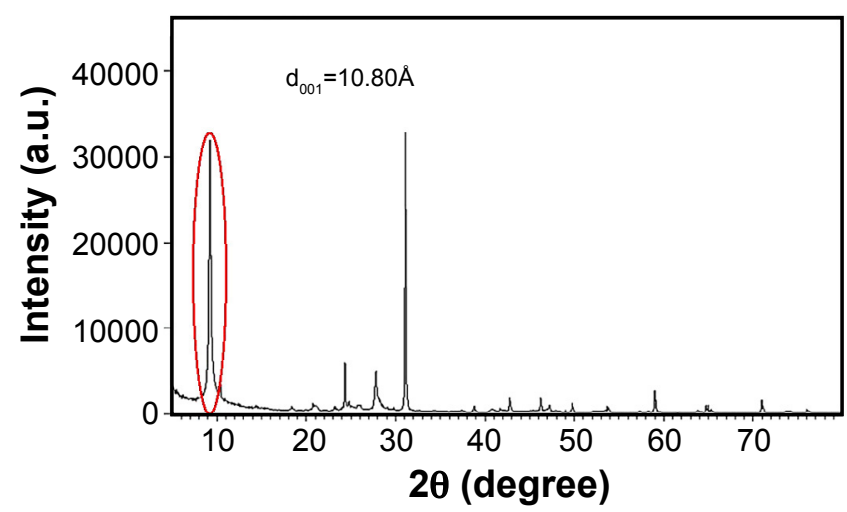

Figure 8: XRD pattern of methoxy-modified kaolinite present in AIR from IOT, highlighting the region that indicates kaolinite$\mathrm{MeOH}$.

[Figura 8: Padrão de DRX da caulinita metoxi-modificada presente no AIR obtido do IOT, com destaque para a região que indica caulinita-MeOH.]

(similar to kaolinite-DMSO). This configuration indicated a typical interlayer structure of methoxy-modified kaolinite before drying, which was composed of monolayer methanol molecules between unmodified siloxane surface and the methoxy-modified inner surface in which the aluminol $(\mathrm{AlOH})$ groups in the interlayer space were converted to AlOMe groups, accompanied by the loss of hydrogen from methanol $(\mathrm{MeOH})$. Besides, a small number of water molecules may have been generated by the combination of the hydrogen loss of $\mathrm{MeOH}$ and the hydroxyl groups of kaolinite [25, 44].

When intercalated with methanol, after having been pre-intercalated with a suitable organic agent, the basal interplanar distance $\left(\mathrm{d}_{001}\right)$ of methoxy-modified kaolinite was $\sim 11 \AA$ Å, before drying. According to [49], when the methoxykaolinite is dried, the value of $\mathrm{d}_{001}$ is close to $8.6 \AA$; when this product undergoes heating to $150{ }^{\circ} \mathrm{C}$, the value of $\mathrm{d}_{001}$ decreases to values close to $8.2 \AA$ without loss of methoxy groups. Thus, the dry methoxy-kaolinite is partially hydrated and a number of $\mathrm{MeOH}$ or water molecules are possibly present in the interlayer region of kaolinite. The reduction of basal distance is attributed mainly to the escape of methanol molecules from the interlayer region during the drying process [25]. The value of $\Delta d_{001}$ between pure kaolinite (K-A, K-SA, and present in AIR; $7.09 \AA$ ) and synthesized methoxy-modified kaolinite (10.80 $\mathrm{A})$ was $3.71 \AA$, which is equal to the diameter of the methanol molecule, indicating that there were methanol molecules in the interlayer region of clay mineral $[49,50]$. The $\mathrm{d}_{001}$ value for the kaolinite$\mathrm{MeOH}(10.80 \AA)$ measured after drying under ambient conditions was larger than those previously reported (8.2$8.6 \AA$ A). Due to insufficient reaction time, methyl groups away from the aluminol surface were not fully embedded into $\mathrm{SiO}_{6}$ macrorings of the adjacent silicate surface, that is, methanol molecules that remained 'loose' in the interlayer region of kaolinite even after the mild drying condition contributed to the larger basal space. The coexistence of grafted methanol molecules and unsubstituted DMSO molecules were not confirmed. If the characteristic peak of kaolinite-DMSO were detected, it would be possible to attribute the largest space in the interlayer region of kaolinite due to the coexistence of these molecules [26].

\section{Kaolinite nanotubes}

In the one-step route, the key to the morphology change is the intercalation of quaternary ammonium salts in the interlayer region of kaolinite, which results in the reduction of structural stiffness and weakening of the interlayer hydrogen bonds [3]. Otherwise, in the two-step route, the deintercalation of the alkylamine promotes morphological change [23]. The efficiency of the formation of nanotubes depends mainly on the type of guest species. In the onestep route, the following factors are determinant: the group type present at the end of the quaternary ammonium salt (typically called the 'head group' of the ammonium salt), the carbon chain length, and the equilibrium anion of charge $\left(\mathrm{Br}, \mathrm{Cl}^{-}\right)$. Another important parameter for the rolling of the layers is the poor interaction between the organic cation (a head group of the intercalating agent) and the methoxymodified octahedral sheet. Guest species containing trimethylammonium groups $\left[\left(\mathrm{CH}_{3}\right)_{3} \mathrm{~N}^{+} \mathrm{H}\right]$ are commonly used because of the interactions between the guest species and the interlayer surface of the methoxy-modified kaolinite are relatively weak, allowing a flexible matrix of interlayer guest species and resulting in simultaneous intercalation and rolling [22]. The organic compounds used were cetyltrimethylammonium bromide [CTAB$\left.\mathrm{CH}_{3}\left(\mathrm{CH}_{2}\right)_{15} \mathrm{~N}(\mathrm{Br})\left(\mathrm{CH}_{3}\right)_{3}\right]$ and cetyltrimethylammonium chloride [CTMACl-CH ${ }_{3}\left(\mathrm{CH}_{2}\right)_{15} \mathrm{~N}(\mathrm{Cl})\left(\mathrm{CH}_{3}\right)_{3}$ ].

The FESEM images of methoxy-modified K-SA reacted with CTAB are shown in Fig. 9. When the methoxy-modified $\mathrm{K}-\mathrm{SA}$ reacted with CTAB, the layers of the clay mineral began to roll and a number of nanotube structures were formed. However, the images also showed the presence of platy or partially curled kaolinite layers. These structures are the result of incomplete delamination and rolling of kaolinite layers. Even though the procedure was carried out at elevated temperature $\left(80{ }^{\circ} \mathrm{C}\right)$, which facilitated the diffusion of organic molecules in the interlayer region of the kaolinite, possibly the concentration of the intercalating and the reaction time was insufficient to promote efficient delamination and rolling. On the other hand, according to $[23,51]$, the formation of nanotube structures depends on the efficiency of the interlayer modification steps, the structural order, and the particle size of the starting clay mineral. According to the X-ray diffraction and FESEM images, K-SA had high purity, but was poorly crystallized, due to the identified microdefects; however, it presented crystals with relatively large particle sizes that favor the processes of intercalation [42, 44]. These factors may explain the formation of nanotube structures, but with low occurrence. It was possible to observe that the length of the nanotube structures formed was smaller than the lateral dimension of the kaolinite matrix. This result indicated that some 
kaolinite layers were fragmented during the intercalation process, indicating possible aggressiveness of CTAB to kaolinite [22, 25]. Fig. 9 suggests that the formation of nanotubes was initiated by the delamination of the surface layers. As a result, nanotube structures remained bound to the platy kaolinite, suggesting that successive intercalation steps would possibly increase the number of rolled layers, affecting deeper layers within the kaolinite particles [23].

Due to the surface characteristics and low presence of microdefects in the kaolinite present in the AIR from IOT, it is possible to affirm that it was a well-crystallized clay mineral, better than K-SA [33, 34]. The particle sizes of the crystallites of the two kaolinites were similar. The variation of the synthesized products was possibly related to the ammonium salt used and the characteristics of the starting clay minerals. According to [51], the number of rolled layers is proportional to the structural order of kaolinite. The products synthesized using CTMACl and kaolinite from IOT
(Fig. 10) were formed by fully rolled plate, showing that the delamination and rolling processes were more intense and the combination between a kaolinite with better structural order and CTMACl was more effective in promoting delamination and rolling of the kaolinite layers, when compared to the procedure using CTAB. The intercalation procedures are more effective in better crystallized raw materials [23, 42]. The results also indicated that CTMACl was less aggressive to kaolinite since no fragmented plate was observed and the CTMACl head group had weaker interaction with the methoxy-modified layer when compared to the CTAB. In addition, the intercalating agents used had carbonic chains of the same size, varying only the volume of the counterion, $\mathrm{Br}^{-}$or $\mathrm{Cl}^{-}$. When bromine, which has a higher atomic radius in relation to chlorine, is present in the ammonium salt, the appropriate carbon chain has a lower number of carbons, which may justify more aggressive intercalation when using CTAB [22]. By increasing the
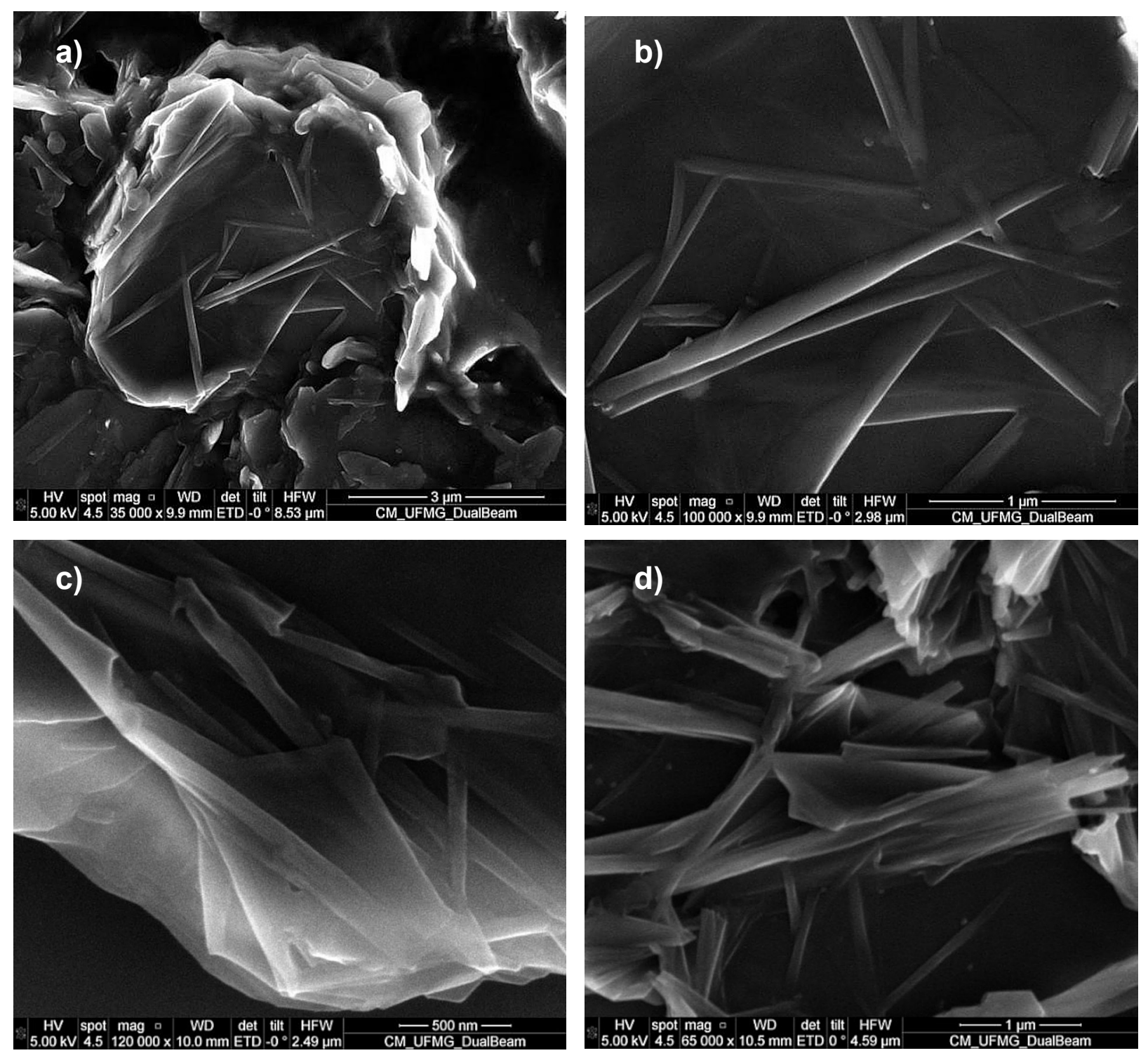

Figure 9: FESEM images of methoxy-modified K-SA reacted with CTAB.

[Figura 9: Imagens de MEVFEG da K-SA metoxi-modificada após reação com CTAB.] 

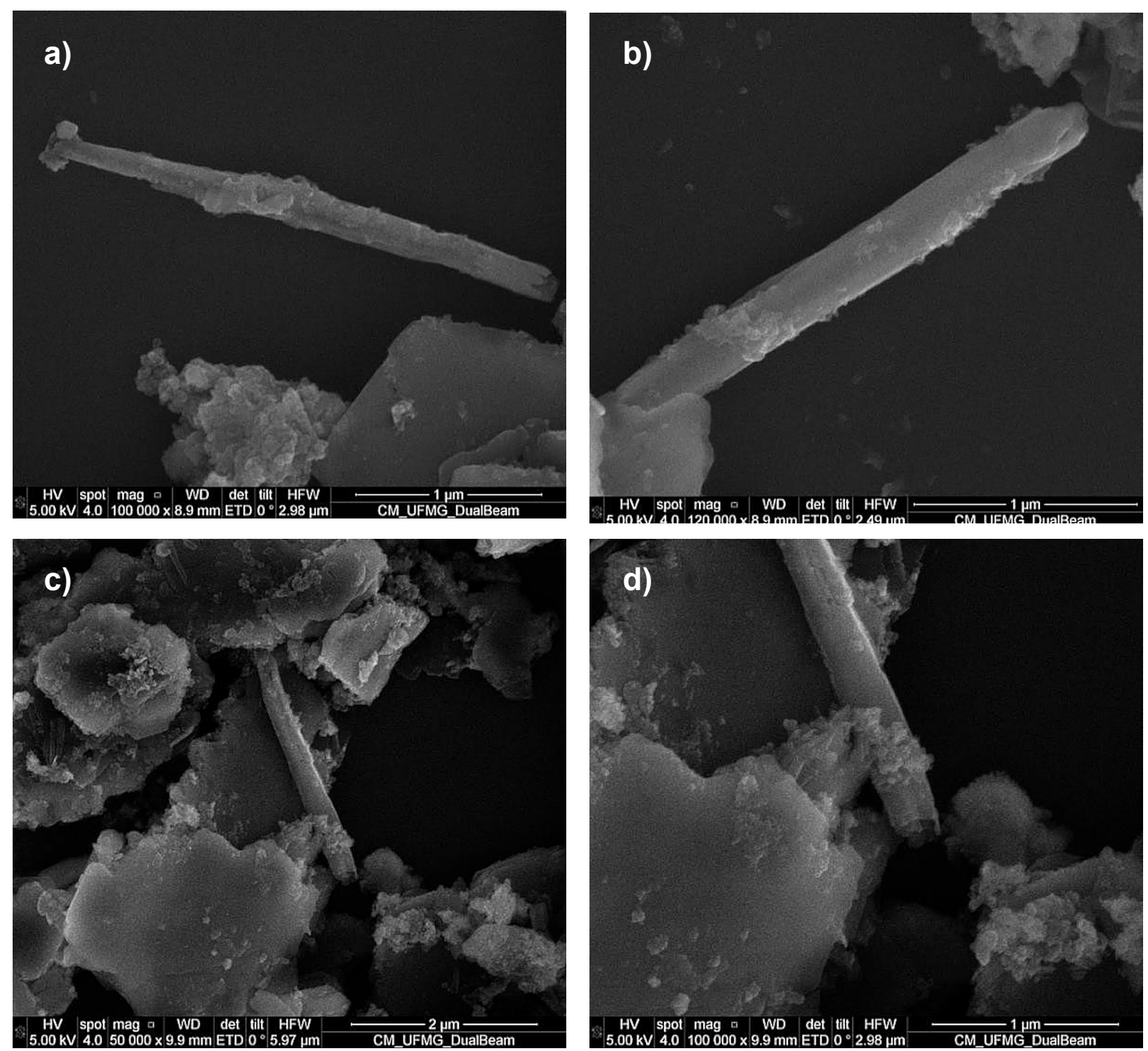

Figure 10: FESEM images of methoxy-modified kaolinite present in the AIR from IOT, reacted with CTMACl.

[Figura 10: Imagens de MEVFEG da caulinita metoxi-modificada presente no AIR obtido do IOT, após reação com CTMACl.]

concentration of the intercalating agent (CTMACl) or by performing repeated procedures, the synthesis yield may be increased, and the concentration of nanotubes in the sample may increase. As observed in the XRD pattern of the AIR sample (Fig. 4b), muscovite and quartz mineralogical phases were identified. These mineralogical phases apparently influenced the yield of the synthesis process. Additional AIR purification steps can eliminate these phases and increase the concentration amount of nanotube. According to [22, 25, 26], the length of the kaolinite nanotubes synthesized using the same intercalating agent (CTMACl) was 100-850, 150-700, and 300-2000 $\mathrm{nm}$, respectively. The product synthesized in this study had an average size of $2990 \mathrm{~nm}$. This increase may be due to the lateral dimension of the kaolinite layers being larger than those used in the cited studies. These results were in agreement with Matusik et al. [23], who affirm that the length of the nanotubes depends on the lateral dimension of the plate of the delaminate clay minerals.
In the two-step procedure, a strong interaction of the amino group with the methoxy-modified kaolinite leads to the formation of nanotube structures because the guest species form a rigid matrix of interlayer intercalated species. Moreover, the adjustment of the interaction between the intercalating agent and the deintercalation promoting solvent must be controlled to achieve a satisfactory degree of delamination and rolling [22]. Another important parameter is the flexibility of the guest molecules. As shown in [22], when larger and more flexible molecules are used to intercalate the methoxy-kaolinite, such as octadecylamine $(\mathrm{C} 18 \mathrm{~N})$ there is no formation of nanotubes, whereas when smaller molecules such as hexylamine $(\mathrm{C} 6 \mathrm{~N})$ are used the formation of nanotube structures is observed. In the two-step procedure, hexylamine [C6N-CH $\left.\left(\mathrm{CH}_{2}\right)_{5} \mathrm{NH}_{2}\right]$ was used as the intercalating and 1,4-dioxane as the deintercalating solvent. In the product synthesized from the two-step procedure (K-SA reacted with C6N, Fig. 11), it was possible to observe superficial nanotube 

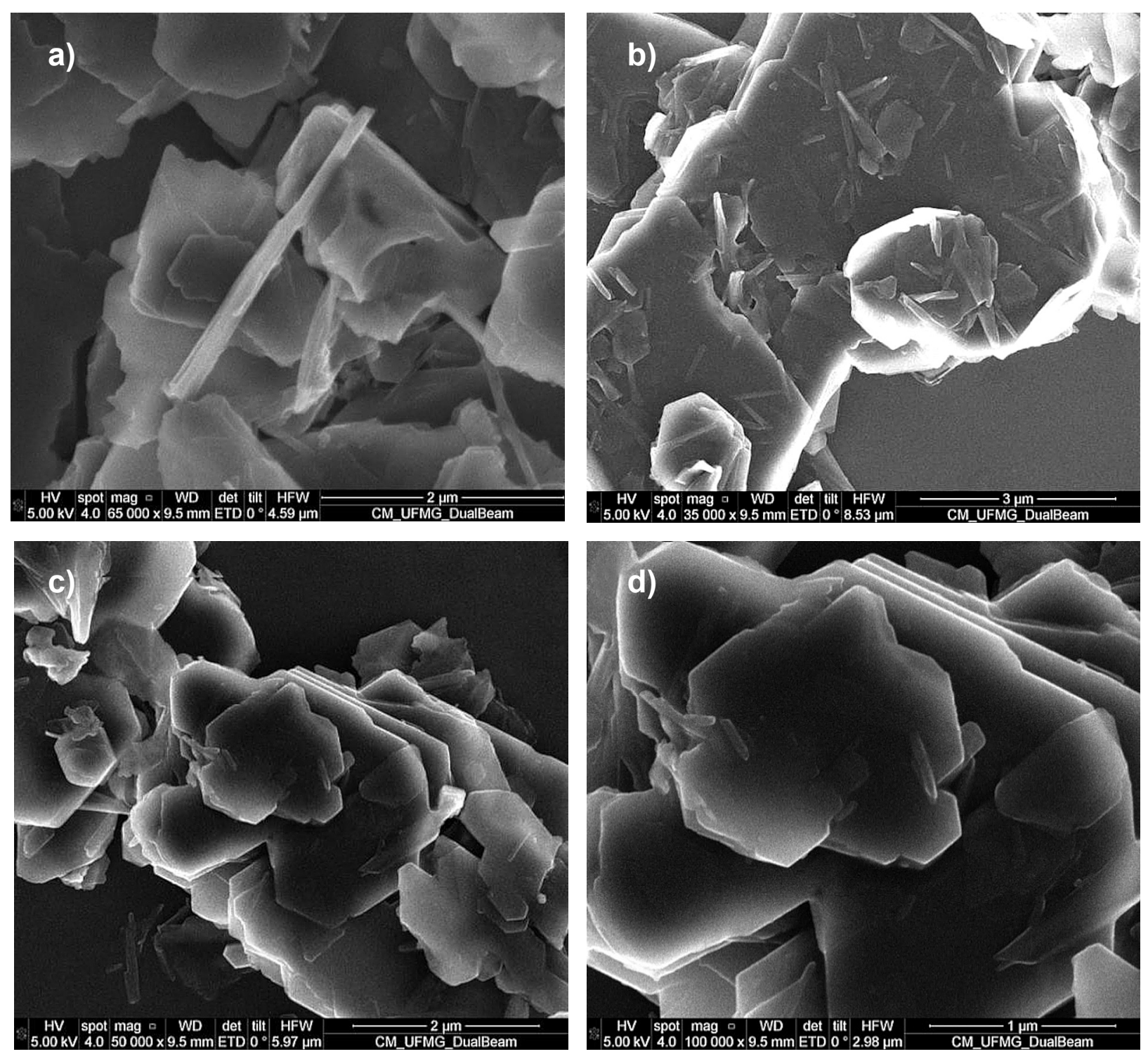

Figure 11: FESEM images of methoxy-modified Sigma-Aldrich kaolinite reacted with C6N.

[Figura 11: Imagens de MEVFEG da caulinita Sigma-Aldrich metoxi-modificada após reação com C6N.]

structures, formed by the delamination of surface clay mineral layers, adhered to the platy kaolinite particles, similar to the product synthesized using CTAB. This fact may be associated with the low concentration of intercalating/deintercalating agents, insufficient intercalation/deintercalation steps, and the use of poorly crystallized kaolinite. Another factor that diminishes the reaction yield is a possible low interaction between the $\mathrm{C} 6 \mathrm{~N}$ and the 1,4-dioxane, which implies a low deintercalation. In Figs. 11c and 11d, it is possible to observe a kaolinite plate with high basal interplanar distance indicating that the intercalation of alkylamine occurred efficiently. However, due to the low interaction with the deintercalating solvent, the formation of nanotube structures was low. By adjusting the interaction between the intercalation compound and the deintercalation solvent, the efficient delamination and rolling can be achieved [22].

No nanotube structures were obtained using the K-A as raw material, regardless of the intercalating agent used.
Although the platy kaolinite was well-defined and presented high structural order, according to $[42,52]$, the particle size strongly interferes with the kaolinite intercalation processes, being more determinant than the crystallinity of the clay mineral. The K-A, similar to the K-SA and the kaolinite obtained from the IOT, presented the $\mathrm{Fe}^{3+}$ ion in its structure; however, only the Amazon kaolinite presented structural $\mathrm{Fe}^{2+}$, resulting in smaller particle size. This may justify a lower yield in the intercalation with dimethyl sulfoxide (76.7\%), consequently inefficiency in the formation of the methoxykaolinite, and the intercalation with the intercalating agents possibly did not occur, or there was not enough time for the intercalation reaction occur, not resulting in morphological alteration.

\section{CONCLUSIONS}

Although at the initial stages, the results achieved 
were encouraging. Even in very low quantities, nanotubes were observed regardless of the intercalating agent used (cetyltrimethylammonium bromide - CTAB, cetyltrimethylammonium chloride - CTMACl, and hexylamine $-\mathrm{C} 6 \mathrm{~N})$. The methods used to concentrate the kaolinite present in the iron ore tailings were efficient, considering the exploratory and scientific character of this experiment. The impurity phases identified in the acidinsoluble residue possibly can be removed by further steps. Although a quantitative analysis was not performed, it was possible to observe the formation of nanotubes from the segregated kaolinite. The segregated kaolinite, even with the $\mathrm{Fe}^{3+}$ ion in its structure, was highly intercalated with dimethyl sulfoxide (DMSO). Methoxy-modified kaolinite was synthesized because, as shown by FESEM, nanotube structures were obtained after the reaction of the methoxymodified product with CTMACl. The reaction yield using the acid-insoluble residue as a raw material possibly may be increased when synthesis is carried out after the remaining impurities are completely eliminated, that is, using an acid-insoluble residue with a higher percentage of kaolinite; additionally, increasing the concentration of the intercalating agent or performing repeated intercalation procedures. Tubular structures were not observed using Amazon kaolinite (K-A) as raw material, possibly due to the presence of structural $\mathrm{Fe}^{2+}$ ions. It is important to emphasize that the presence of $\mathrm{Fe}^{3+}$ ions in the kaolinite structure did not interfere in the efficiency of the intercalation with DMSO, methoxy-modification, intercalation, and synthesis of nanotube structures. A comparative analysis of the structure of synthesized products and natural halloysite nanotubes is the object of study of the next stages of the project.

\section{ACKNOWLEDGMENTS}

Financial support from the Brazilian Mining Company Vale S.A. and the technological support from CM-UFMG are gratefully acknowledged.

\section{REFERENCES}

[1] L.C.R. de Andrade, "Caracterização de rejeitos de mineração de ferro, in natura e segregados, para aplicação como material de construção civil”, Doct. Thesis, Fed. Un. Viçosa, Brazil (2014).

[2] D. Janacek, L. Kvitek, M. Karlikova, K. Pospiskova, I. Safarik. Appl. Clay Sci. 162 (2018) 10.

[3] P. Yuan, A. Thill, F. Bergaya, Nanosized tubular clay minerals, halloysite and imogolite, Elsevier (2016).

[4] C.E.Y. Erpek, G. Ozkoc, U. Yilmazer, Polym. Compos. 38, 11 (2017) 2337.

[5] P. Yuan, P.D. Southon, Z. Liu, M.E.R. Green, J.M. Hook, S.J. Antill, C.J. Kepert. J. Phys. Chem. C 112, 40 (2008) 15742 .

[6] B. Singh, Clay Clay Miner. 44, 2 (1996) 191.

[7] C. Detellier, R.A. Schoonheydt, Elements 10, 3 (2014) 201.
[8] A. El Haddar, E. Gharibi, A. Azdimousa, N. Fagel, I.-E. El Amrani El Hassani, M. El Ouahabi, Clay Miner. 53, 1 (2018) 65.

[9] X. Li, D. Wang, Q. Liu, S. Komarneni, Appl. Clay Sci. 168 (2019) 421.

[10] V.M. Abbasov, H.C. Ibrahimov, G.S. Mukhtarova, E. Abdullayev, Fuel 184 (2016) 555.

[11] J. Jin, Y. Zhang, J. Ouyang, H. Yang, Phys. Chem. Miner. 41, 5 (2014) 323.

[12] M.R. Dzamukova, E.A. Naumenko, Y.M. Lvov, R.F. Fakhrullin, Sci. Rep. 5 (2015) 10560.

[13] Y.M. Lvov, M.M. Devilliers, R.F. Fakhrullin, Expert Opin. Drug Deliv. 13, 7 (2016) 977.

[14] M. Massaro, A. Campofelice, C.G. Colletti, G. Lazzara, R. Noto, S. Riela, Appl. Clay Sci. 160 (2018) 186.

[15] Y. Chen, Y. Zhang, J. Liu, H. Zhang, K. Wang, J. Chem. Eng. 210 (2012) 298.

[16] E. Abdullayev, V. Abbasov, A. Tursunbayeva, V. Portnov, H. Ibrahimov, G. Mukhtarova, Y. Lvov, CS Appl. Mater. Interfaces 5, 10 (2013) 4464.

[17] P.C. Ferrari, F.F. Araujo, S.A. Pianaro, Cerâmica 63, 368 (2017) 423.

[18] M. Liu, Z. Jia, D. Jia, C. Zhou, Prog. Polym. Sci. 39, 8 (2014) 1498.

[19] R.L. Frost, X. Li, Q. Liu, H. Cheng, S. Zhang, J. Colloid Interf. Sci. 444 (2015) 74.

[20] J.E.F.C. Gardolinski, G. Lagaly, Clay Miner. 40, 4 (2005) 537.

[21] J.E.F.C. Gardolinski, G. Lagaly, Clay Miner. 40, 4 (2005) 547.

[22] Y. Kuroda, K. Ito, K. Itabashi, K. Kuroda, Langmuir 27, 5 (2011) 2028.

[23] J. Matusik, A. Gaweł, E. Bielanska, W. Osuch, K. Bahranowski, Clay Clay Miner. 57, 4 (2009) 452.

[24] B. Singh, D.R. Mackinnon, Clay Clay Miner. 44, 6 (1996) 825.

[25] P. Yuan, D. Tan, F. Annabi-Bergaya, W. Yan, D. Liu, Z. Liu, Appl. Clay Sci. 83-84 (2013) 68.

[26] H. Xu, X. Jin, P. Chen, G. Shao, H. Wang, D. Chen, H. Lu, R. Zhang, Ceram. Int. 41, 5 (2015) 6463.

[27] T.F. Bates, F.A. Hildebrand, A. Swinedford, Am. Mineral. 35 (1950) 463.

[28] P. Yuan, D. Tan, F. Annabi-Bergaya, Appl. Clay Sci. 112-113 (2015) 75.

[29] NBR ISO 2597-2, "Iron ores: determination of total iron content, Part 2, titrimetric methods after titanium (III) chloride reduction", Ass. Bras. Norm. Téc., S. Paulo (2013). [30] O. Castelein, L. Aldon, J. Olivier-Fourcade, J.C. Jumas, J.P. Bonnet, P. Blanchart, J. Eur. Ceram. Soc. 22, 11 (2002) 1767.

[31] C.A.S. Pérez, D. Gobbi, J.L.N. Marcos, C. Paduani, J.D. Ardisson, Cerâmica 50 (2004) 115.

[32] S. Petit, A. Decarreau, Clay Miner. 25, 2 (1990) 181.

[33] M. Zbik, R.S.C. Smart, Clay Clay Miner. 46, 2 (1998) 153.

[34] J. Du, G. Morris, R.A. Pushkarova, R.S.C. Smart, Langmuir. 26, 16 (2010) 13227. 
[35] J.C. Araujo, J.T. Assis, V.I. Monine, L.C. Bertolino, Rev. Matér. 11, 3 (2006) 361.

[36] A.H. Cuttler, Clay Miner. 15, 4 (1980) 429.

[37] J.T. Kloprogge, Spectroscopic methods in the study of kaolin minerals and their modifications, Springer (2019) 434.

[38] L.A. Silva, "Síntese e caracterização de nanopartículas de hematita e de ferro zerovalente sintetizadas a partir de cloreto férrico", Doct. Thesis, Fed. Un. Santa Catarina, Brazil (2015).

[39] S.K. Giri, N.N. Das, G.C. Pradhan, Powder Technol. 214, 3 (2011) 513.

[40] R. Sakthivel, R. Kumar, R. Behura, B.K. Mishra, D. Das, J. Alloys Compd. 645 (2015) 398.

[41] R.M. Cornell, U. Shwertmann, The iron oxides: structure, properties, reactions, occurrences and uses, $2^{\text {nd }}$ ed., Wiley-VCH (2003) 664.

[42] Y. Deng, G. Norman White, J.B. Dixon, J. Colloid Interf. Sci. 250, 2 (2002) 379.

[43] D.L. Guerra, J.A. Sousa, C. Airoldi, R.R. Viana, Cerâmica 54, 331 (2008) 273.
[44] Q. Liu, S. Zhang, H. Cheng, F. Gao, C. Liu, B.J. Teppen, Appl. Clay Sci. 151 (2018) 46.

[45] J.A. Mbey, F. Thomas, C.J. Ngally Sabouang, Liboum, D. Njopwouo, Appl. Clay Sci. 83-84 (2013) 327.

[46] G. Lagaly, M. Ogawa, I. Dékány, in "Handbook of clay science" 1, F. Bergaya, B.K.G. Theng, G. Lagaly (Eds.), Elsevier (2006) 309.

[47] P.J.R. Uwins, I.D.R. Mackinnon, J.G. Thompson, A.J.E. Yago, Clay Clay Miner. 41, 6 (1993) 707.

[48] G.J. Churchman, J.S. Whitton, G.G.C. Claridge, B.K.G. Theng, Clay Clay Miner. 32, 4 (1984) 241.

[49] Y. Komori, H. Enoto, R. Takenawa, S. Hayashi, Y. Sugahara, K. Kuroda, Langmuir 16, 12 (2000) 5506.

[50] L. Zhang, C. Wang, Z. Yan, X. Wu, Y. Wang, D. Meng, H. Xie, Appl. Clay Sci. 86 (2013) 106.

[51] J. Matusik, E. Wisła-Walsh, A. Gaweł, E. Bielanska, K. Bahranoowski, Clay Clay Miner. 59, 2 (2011) 116.

[52] P.J.R. Uwins, I.D.R. Mackinnon, J.G. Thompson, in $28^{\text {th }}$ Ann. Meet., Lunar Planet. Inst., Houston (1991) 154.

(Rec. 19/06/2019, Rev. 10/09/2019, 28/10/2019, Ac. 30/10/2019) 